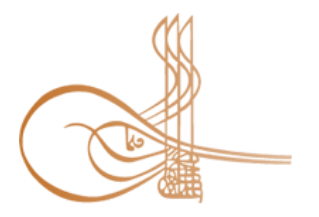

www.turkishstudies.net/social
Turkish Studies - Social Sciences

eISSN: 2667-5617

Research Article / Araştırma Makalesi

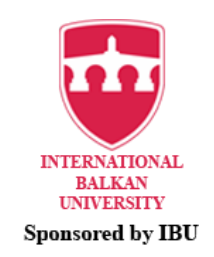

Sponsored by IBU

\title{
Fırsat mı Tehdit mi?: Özgürleşim ve Sınırlayıcı Alanları ile Yeni Nesil Gazetecilik ${ }^{*}$ \\ Opportunity or Threat?: New Generation Journalism with Freedom and Limiting Areas
}

\author{
Tuğçe Esin Pınarbaşı ${ }^{* *}$ - Fatma Kübra Astam ${ }^{* * *}$
}

\begin{abstract}
Technological options, which is one of the forces prioritizing the change in social structure, has transformed some routine Works in political, economic and social fields. This developments are continuing by interconnected like a chain link day by day. Technological developments, as in different fields in the process, have brought about a new generation of journalism by transforming journalistic practices the formal cause of news and news experiments. Data journalism which started to be experienced with the aim of creating a meaningful whole from the data gaining special importance in digital media, robot journalism about adaptation of journalism under robotics and artificial intelligence, drone journalism that enables collecting news from the sky as a result of the developments in unmanned aerial vehicles, augmented reality journalism started with the adoption of augmented reality technology to journalism fiel and blockchain journalism started with the development of various journalism platforms on the blockchain. In this study, data journalism, robot journalism, drone journalism, augmented reality journalism, blockchain journalism applications and their applications in the field were investigated as new generation journalism practices. New generation journalism contributed to news gathering, publishing and reception processes. The study focuses on the emancipation and restrictive areas of new generation journalism with a two-way perspective when evaluated in terms of journalist, news and reader / audience. It has been concluded that the solution proposals to be developed for the problems identified in the application areas are important in terms of maintaining the balance between the privacy of private life and the public's right to information
\end{abstract}

Structured Abstract: Many commonly used objects are equipped with information and communication technologies today. Advances in new communication technologies have not only deeply affected social and social life, but they have also been a source of transformations. These technologies restructured the individual, language and culture. Almost everything defined as "traditional" in the process has tried to harmonize with technology. These changes, which are felt in all areas of social life, have been experienced at the top level in the media field. Developments in information and information technology have also brought a

\footnotetext{
* 6-7 Haziran 2020 tarihleri arasında İstanbul Sabahattin Zaim Üniversitesi tarafından düzenlenen Sosyal Bilimler Lisansüstü Öğrenci Kongresi’nde “Özgürleştirici ve Kısıtlayıcı Yönleriyle Yeni Nesil Gazetecilik” başlı̆̆ı ile sözlü bildiri olarak sunulan çalışmanın genişletilmiş halidir.

** Doktora Öğrencisi, Anadolu Üniversitesi, Sosyal Bilimler Enstitüsü, Basın ve Yayın Ana Bilim Dalı

PhD Student, Anadolu University, Institute of Social Sciences, Department of Journalism

ORCID 0000-0002-6790-0420

tugceesinpinarbasi@anadolu.edu.tr

**** Doktora Öğrencisi, Anadolu Üniversitesi, Sosyal Bilimler Enstitüsü, Basın ve Yayın Ana Bilim Dalı PhD Student, Anadolu University, Institute of Social Sciences, Department of Journalism ORCID 0000-0001-5056-4558

fatmakubraastam@anadolu.edu.tr

Cite as/ Atıf: Pınarbaşı, T.E. \& Astam, F.K. (2020). Fırsat mı tehdit mi?: özgürleşim ve sınırlayıcı alanları ile yeni nesil gazetecilik. Turkish Studies - Social, 15(5), 2675-2692. https://dx.doi.org/10.47356/TurkishStudies.45338

Received/Geliş: 15 July/Temmuz 2020

Checked by plagiarism software

Accepted/Kabul: 20 August/Ağustos 2020

Published/Yayın: 30 August/Ağustos 2020

Copyright $($ INTAC LTD, Turkey

CC BY-NC 4.0
} 
number of new habits for individuals to reach the news. When individuals turn from traditional media to online environments in order to meet the need for news, news organizations are in new searches in order to maintain their position and sustain their existence.

According to Pavlik and Bridges (2013: 5), technological developments affect journalism basically in four ways. The first is the changes and transformations in the practices of giving and receiving news. Changes in news gathering and writing, focus on development potentials in productivity and access to information. The second is the emphasis that technological developments change news and media organizations, business practices and models. New communication environments restructure the presentation of the news, greatly reducing the cost of communicating news, thereby transforming the news and business model. The third point is important for the audience. The relationship between the media and the target audience has been restructured as the audience adapted to the developments and transformed from passive buyers to relatively active ones. This transformation has the potential to improve the relationship between journalists, news organizations and the target audience by increasing the interaction between buyers, news and journalists. The fourth and the transformation, which will be discussed in this article, is an evaluation on the diversification of technological developments, news and media content. The importance of this content transformation is that it offers a number of liberation spaces as well as all kinds of innovations included in the life of individuals, as well as the potential to create a restrictive space. In this study, as a result of the technical transformation of the media; data journalism, robot journalism, drone journalism, augmented reality journalism and blockchain journalism will be evaluated as liberalizing and limiting aspects as new generation journalism practices.

Thanks to the developing communication technologies, the process of gathering news and the ways of reaching the news are becoming more and more diversified. The news delivery process, which started with the use of traditional media, is continued on digital platforms with the development of new communication environments. With the adaptation of technological developments to the field of journalism, new generation journalism types have emerged and the border areas of journalism, journalist and news have expanded. While contributing to the new generation journalism news gathering, publishing and reception processes, it also created problem areas. When new generation journalism is evaluated in terms of journalist, news and reader / audience, it is observed that there are both liberation and restrictive areas. Focusing on emancipation and restrictive areas in terms of journalism practices; It can be said that the news, which is handled one way and vertically, differs, time savings are achieved with automated content and the cost of news gathering is reduced. News with new generation journalism; has gained speed, diversity, timeliness and innovation. The content of news items such as text, photos and videos are enriched with different techniques. The use of elements supporting the background ensured that the news was not removed from the context. The use of different techniques and ways made it possible for the news to offer a versatile perspective.

New generation journalism has developed rescuer practices in cases where journalists are not safe, and it has given access to areas with spatial limitations that they cannot reach. It has brought out applications such as environment, peace and rights journalism, which are among its new areas of expertise, and has enabled the development of investigative journalism. Although there are opinions that a new generation of journalism will lead to the unemployment of journalists, it has been observed that a new staff named news automation editor has been formed and the role of the editors is still important. The fact that news organizations invested technically and qualitatively to catch up with technological developments has increased the cost. The fact that the organizations do not have the same economic and technological conditions also complicated the adaptation process to the new generation journalism types. Due to the continuing transformation in the journalism sector and the differentiation of journalistic practices in this process, it is one of today's requirements that journalists improve their technology use skills.

Keywords: New Generation Journalism, Data Journalism, Robot Journalism, Drone Journalism, Augmented Reality Journalism, Blockchain Journalism.

Öz: Toplumsal yapıdaki değişimi önceleyen güçlerden biri olan teknoloji; kültürel, siyasal, ekonomik ve sosyal alanlarda birtakım rutin işleyişleri dönüştürmüştür. Bu gelişmeler adeta bir zincirin halkası gibi her geçen gün birbirine eklemlenerek devam etmektedir. Süreç içinde farklı alanlarda olduğu gibi teknolojik gelişmeler gazetecilik pratiklerini, haberin biçimsel özelliklerini ve haber alma deneyimlerini dönüşüme uğratarak yeni nesil gazeteciliği ortaya çıkarmıştır. Dijital ortamlarda ayrı bir önem kazanan verilerden 
anlamlı bir bütün oluşturma amacıyla deneyimlenmeye başlanan veri gazeteciliği, robotik ve yapay zeka sistemlerinin gazetecilik alanına uyarlanmasıyla gerçekleştirilen robot gazetecilik, insansız hava araçları üretimindeki gelişmeler sonucu gökyüzünden haber toplamaya olanak sağlayan drone gazeteciliği, artırılmış gerçeklik teknolojisinin gazetecilik alanına uyarlanmasıyla başlayan artırılmış gerçeklik gazeteciliği ve blokzincir üzerinde çeşitli gazetecilik platformlarının geliştirilmesiyle yapılmaya başlanan blokzincir gazeteciliği, yeni nesil gazetecilik uygulamalarıdır. Bu çalışmada, yeni nesil gazetecilik pratikleri olarak veri gazeteciliği, robot gazeteciliği, drone gazeteciliği, artırılmış gerçeklik gazeteciliği, blokzincir gazeteciliği uygulamalarındaki gelişmeler ve alandaki pratikleri incelenmiştir. Yeni nesil gazetecilik haber toplama, yayınlama ve alımlama süreçlerine katkı sağlamıştır. Çalışmada, gazeteci, haber ve okuyucu/izleyici açısından değerlendirildiğinde çift yönlü bir bakış açısıyla yeni nesil gazeteciliğin özgürleşim ve sınırlayıcı alanlarına odaklanılmıştır. Uygulama alanlarında tespit edilen sorunlara yönelik olarak geliştirilecek çözüm önerilerinin, özel yaşamın gizliliği ile kamunun bilgilenme hakkı arasındaki dengeyi koruması açısından önem arz ettiği sonucuna ulaşılmıştır.

Anahtar Kelimeler: Yeni Nesil Gazetecilik, Veri Gazeteciliği, Robot Gazetecilik, Drone Gazeteciliği, Artırılmış Gerçeklik Gazeteciliği, Blokzincir Gazeteciliği.

\section{Giriş}

Yaygın olarak kullanılan pek çok nesne günümüzde bilgi ve iletişim teknolojileri ile donatılmıştır. Yeni iletişim teknolojilerindeki ilerlemeler toplumsal ve sosyal hayatı derinden etkilemekle kalmayıp aynı zamanda dönüşümlerin yaşanmasına da kaynaklık etmiştir. $\mathrm{Bu}$ teknolojiler bireyi, dili ve kültürü yeniden yapılandırmıştır. Süreç içinde "geleneksel" olarak tanımlanan neredeyse her şey teknoloji ile uyumlaşma çabası göstermiştir. Toplumsal yaşamın her alanında hissedilen bu değişimler medya alanında da üst seviyede yaşanmıştır. Bilgi ve enformasyon teknolojisinde yaşanan gelişmeler bireylerin haberlere ulaşmasında da bir takım yeni alışkanlıklar kazandırmıştır. Bireyler haber alma ihtiyacını karşılamak için geleneksel medyadan çevrimiçi ortamlara doğru yönelince haber kuruluşları olduğu konumu koruyabilmek ve varlıklarını sürdürebilmek adına yeni arayışlar içine girmiştir.

Pavlik ve Bridges'e (2013: 5) göre, teknolojik gelişmeler gazeteciliği temelde dört açıdan etkilemektedir. Birincisi, haber verme ve haber alma pratiklerinde yaşanan değişim ve dönüşümlerdir. Haber toplama ve yazma aşamasındaki değişiklikler, verimlilik ve bilgiye erişim noktasındaki gelişim potansiyellerine odaklanma söz konusudur. İkincisi, teknolojik gelişmelerin haber ve medya kuruluşlarını, iş uygulamalarını ve modellerini değiștirdiği yönündeki vurgudur. Yeni iletişim ortamları haberin sunumunu yeniden yapılandırmakta, haber iletmedeki maliyeti büyük ölçüde azaltmakta böylelikle de haber ve iş modelini dönüştürmektedir. Üçüncü nokta izleyiciler açısından önem arz etmektedir. İzleyicilerin gelişmelere uyum sağlamasıyla birlikte pasif alıcılardan görece aktif alıcılara dönüşmesiyle, medya ve hedef kitle arasındaki ilişki yeniden yapılanmıştır. Bu dönüşüm alıcı, haber ve gazeteciler arasındaki etkileşimi artırarak gazeteciler, haber kuruluşları ve hedef kitle arasındaki ilişkiyi geliştirme potansiyeline sahiptir. Dördüncü ve bu makalede ele alınacak olan dönüşüm ise teknolojik gelişmeler, haber ve medya içeriğindeki anlatım unsurlarının çeşitlenmesine yönelik bir değerlendirmedir. Söz konusu bu içerik dönüşümünün önemi, bireylerin hayatına dahil olan her türlü yenilikte olduğu gibi bir takım özgürleşim alanı sunmasıyla birlikte aynı zamanda sınırlayıcı bir alan oluşturma potansiyelini de içinde barındırmasıdır. Bu çalışmada, medyanın teknik anlamdaki dönüşümü neticesinde; veri gazeteciliği, robot gazeteciliği, drone gazeteciliği, artırılmış gerçeklik gazeteciliği ve blokzincir gazeteciliği yeni nesil gazetecilik pratikleri olarak özgürleştirici ve sınırlayıcı yönleri ile değerlendirilecektir.

\section{Veri Gazeteciliği}

Gündelik hayatın önemli bir unsuru olan veri, geçmişten günümüze farklı alanlarda kullanılmaktadır. Yaygın olarak birçok şeyin sayılarla ifade edilmesi gelişen teknoloji ile beraber 
büyüyen verilerin doğru bir biçimde oluşturulmasını, hızlı bir şekilde aktarılmasını ve anlamlı sonuçlar çıkarılacak şekilde işlenmesini önemli hale getirmiştir. Veri; "bilgi, data", "olgu, kavram veya komutların, iletişim, yorum ve işlem için elverişli biçimli gösterimi" ve "gözlem ve deneye dayalı araştırmanın sonuçları" şeklinde farklı tanımlamalarla açıklanmaktadır (https://sozluk.gov.tr/, 2020). Bir ya da birden fazla bilgi kümelerinden oluşan veri, bilginin yapılandırılıp kayıt altına alınmasını ve kolay analiz edilebilmesini sağlamaktadır. Yaş, isim, telefon numarası, bir toplama işleminin sonucu ya da sınıfın yaş ortalaması birer veridir. Veriler genellikle araştırma, gözlem, deney, sayım, ölçüm yoluyla elde edilmektedir (Dağ, 2016).

1600'lü y1llarda Londra'da belirli ücret karşıllı̆ında ölüm ve doğum verilerinin haftalık olarak satılmasıyla verilere farklı değerler yüklenmeye başlanmıştır (Rogers vd., 2017: 5). Veri gazeteciliğine ilk örnek, 1821 yılında Manchester'da okula giden öğrenci sayısının ve öğrenci başına düşen masrafların veri olarak kullanıldığı The Guardian gazetesinde yayınlanan haberdir (Rogers, 2013). Türkiye'de veri gazeteciliği 1930 yılında Cumhuriyet gazetesinde veremle ilgili yapılan bir haberle başlamıştır. Veri, veri gazeteciliği, veri görselleştirme, veri okuryazarlığının gelişimine katkı sunmak ve veri analizi atölyeleri düzenlemek amacıyla 2012 yılında Dağ Medya tarafından www.verigazeteciligi.com adında bir internet sitesi kurulmuştur (www.verigazeteciligi.com, 2012).

Bilgisayar destekli raporlamaya dayanan ve araştırmacı gazeteciliğin gelişen bir türü olan veri gazeteciliği, "günümüzde geleneksel gazetecilik çalışma yöntemlerinin veri analizi, programlama ve görselleştirme teknikleriyle, gelişmekte olan bir hikaye anlatım biçimi" olarak tanımlanmaktadır (Nygren vd., 2012). Gray vd.'ye (2012) göre veri gazeteciliği; veri seti edinme, verilerin temizlenmesi, veri görselleştirme, analiz ve yorumlama, belgelerin işaretleri, hikaye, bilgi görselleştirme ve uygulama tasarımı olmak üzere sekiz aşamada gerçekleştirilmektedir.

Teknolojik gelişmeler, geleneksel gazetecilik pratiklerinde de dijital kaynaklardan haber arama ve görselleştirme gibi ihtiyaçları beraberinde getirmiştir. Bradshaw'e (2012) göre, veri gazeteciliği "geleneksel haberin yeni olanaklara sahip olması ve büyük ölçekli kitlelere dijital bilgiyle oluşturulmuş hikâyeyi yayma firsatı sunması" olarak ifade edilmektedir. Veri gazeteciliği, haberin arka planından bahsedilerek dünü ile bugününe kadar uzanan sürecin, olayın öncesi ve sonrası hangi aşamada olduğu bilgisinin verilerle sunulması olarak açıklanabilir. Büyük boyutlardaki veriyi süzen, binlerce veri setini analiz edebilen, kodlama ve program becerisine sahip olan kişiler veri gazetecisi olarak tanımlanabilir.

Veri gazeteciliği açısından önem taşıyan iki kavram "büyük veri” ve "açık veri”dir. Büyük veri, geleneksel veri tabanı yazılım araçlarının depolayıp yönetemediği ve analiz edemediği veya bunları yapma kapasitesini aşan büyüklükteki verileri ifade etmek için kullanılmaktadır (Schönberger ve Cukier, 2013: 6). Büyük veri kavramının 2000 yılında Diebold tarafindan kullanıldı̆̆ı ifade edilse de (Gürsakal, 2014: 19), ilk kez 1990'larda Mashey tarafindan kullanılmıştır (Diebold, 2012). Büyük veri, Cox ve Ellsworth (1997) tarafindan veri setlerinin çok büyük olduğundan ve bilgisayar sisteminin belleğini, disklerini ve hatta harici diskleri dahi doldurduğundan bahsedilerek "büyük veri problemi" adıyla, bir sorun olarak ele alınmıştır. $\mathrm{Bu}$ noktada, büyük verinin kimin kontrolünde olduğu ve nasıl kullanıldığı veri gazeteciliği konusunda önem kazanmıştır. Manovich (2011: 10-11), "büyük veri toplumu" nun yeni "veri sınıfları" olarak insan ve kuruluşları üç gruba ayırır. Bunlardan ilki veriyi hem bilinçli olarak hem de dijital ayak izlerini bırakarak oluşturanlar, ikincisi veriyi toplamak için gerekli imkanlara sahip olanlar, üçüncüsü ise veri analizi tecrübesi bulunanlardır. İlk gruba internet veya cep telefonu kullananlar girmektedir, ikinci grup daha küçükken üçüncü grup ondan da küçüktür. Bu gruplandırmaya göre gazetecilerin konumu değişiklik göstermektedir. Gazeteciler; internet teknolojisinin tüketicisi olarak birinci, haberin kaynağına ulaşırken ikinci, veri işleme aşamasında ise üçüncü gruba dâhil olmaktadır. Büyük veriyle ilgili yürütülen çalışmalar incelendiğinde, genellikle gazetecilikle ilgili olduğu gözlenmiştir. 2014 yılında hazırlanan "Big Data for Media" adlı raporda medya için büyük 
veri stratejilerinin kitleyi içermesi gerekliliği vurgulanmıştır. Rapora göre; hedef kitlenin daha iyi anlaşılması için kitle analitikleri, kamu ve özel kaynaklı veri tabanlarının analizi için gazetecilik öyküleme veri tabanları, metin üretimini otomatikleştiren araçlar, kullanışlı içerikler, ilgi çekici içeriklerin ayrımı ve sosyal medyada yüksek miktarda video ve diğer içerikleri yönetmek ve bulmak için gerekli araçlar kullanılmalıdır (Stone, 2014).

Verinin bilgiye dönüştürülmesinde haber açısından üretim, dağıtım ve tüketimde değişikler yaşanmıştır. Büyük verinin neden olduğu bu dönüşüm açık verinin önemini de ortaya çıkarmıştır. Açık veri, herhangi bir yasal, teknolojik veya sosyal kısıtlama olmaksızın herkes tarafindan ücretsiz, özgürce, tekrar kullanılabilen ve dağıtılabilen veri olarak tanımlanmaktadır (Open Knowledge, 2020). Açık veri ve gazetecilik ilişkisinde kaynağa erişim sorunu, kaynağın güvenirliği ve verinin demokratikleştirici yönü noktasında güncel tartışmalar mevcuttur. Bu noktada veri gazeteciliğinde kurumların verilerini ya da bilgilerini şeffaf olarak paylaşması ve talep eden herkesin ulaşması önemlidir. Verilerin güvenilir kaynaktan elde edilmesi ve derinlikli haber yapmak amacıyla kullanılması araştırmacı gazeteciliğe de katkı sağlamaktadır.

İnternet ortamındaki veriler, gazetecilerin haber üretim sürecinde büyük bir rol oynamaya başlamıştır. Tek yönlü ve dikey olarak ele alınan haber farklılaşmış, arşivlerden ya da çevrimiçi belgelerden elde edilen bilgiler analiz edilerek olayın tüm süreci veri ile ifade edilen habere dönüşmüsstür. $\mathrm{Bu}$ dönüşüm, gazetecilikte yeni uzmanlık alanları olan çevre, barış ve hak gazeteciliği gibi uygulamaları ortaya çıkarmıştır. Veri ve haber ilişkisinde değişmeyen tek yön ise kaynakların doğrulanması gerekliliğidir (Howard, 2014: 14). Türkiye'de veri bankalarının ${ }^{1}$ yaygın olmaması, verilerin belirli platformlardan paylaşılması ve ulaşılabilir olan verilerin az olması veri gazeteciliğinin gelişimine ket vurmaktadır. Ancak, çevrimiçi uygulamaların haber üretim ve tüketim sürecinde daha fazla tercih edildiği dikkate alındığında, verilerin öneminin daha da artacağı ve haber kaynağı noktasında stratejik olması beklenmektedir. Mobil haber uygulamalarında da algoritmalar tarafindan okuyucunun ilgi alanlarına göre kişiselleştirilmiş haberlerin oluşturulmasında kullanıcıların sağladığı verilerden yararlanılmaktadır. $\mathrm{Bu}$ noktada, kullanıcı gizliliğinin ihlal edilmesinin, bilgi güvenliğinin sağlanamamasının ve büyük veriye erişim olanaklarının herkes için eşit olmamasının etik sorunlar arasında yer aldığı vurgulanmalıdır. Verilerin kamu hizmetlerinde kullanılması yerel, ulusal yönetim birimleri ve vatandaş açısından daha verimli bir sürecin işlemesine olanak sağlasa da etik konusunda fikir ayrılıkları söz konusudur. Bu noktada veri koruma ve güvenlik becerilerinin öneminin artırılmasının da altı çizilmelidir.

Yenilikleri takip eden, teknoloji kullanım becerilerini geliştiren ve verilere odaklanan gazeteciler açısından veri gazeteciliğinin haberin üretim sürecini kolaylaştırdığı söylenebilir. Günümüzde haberde hikayeleştirme tekniğini kullanmak isteyen gazeteciler veri gazeteciliğinden yaygın olarak yararlanmaktadır. Bu bağlamda, ayırıcı bir özellik olarak raporlama tekniği öne çıkmaktadır. Veri gazetecileri, okuyucuların karmaşık verileri anlamlandırma süreçlerinde de rol oynamaktadır. Ayrıca uygulamalarda, robotik bir gazetecilik gelişse de hala insan ilişkilerini yansıtmak ve hikaye anlatımı önemini korumaktadır. Dijital iletişimin ve veri gazeteciliğinin bireylerin demokratikleşme süreçlerine de katkısı bulunduğu görüşü yaygındır. Bireyler haberde kullanılacak verilere, şeffaflık sağlayacağını düşündükleri bilgiye hatta hikayenin nasıl oluşturulacağına kadar katkı sunabilmektedir.

Karşı bir görüş ise içeriği zenginleştirmesinin aksine kaynakların sınırlılığı noktasındaki tektipleşme vurgusudur. Verinin ayrı bir boyut kazandırdığı etik, mahremiyet, gözetim, manipülasyon ve güç dengesizliği gibi konular üzerinde ise akademik tartışmalar devam etmektedir (Lewis ve Westlund, 2015: 459-460; Richterich, 2018: 34-36).

\footnotetext{
${ }^{1}$ Belli bir konudaki verilerin derlenip biriktirilmesini ve ilgililer tarafından kolay bir biçimde erişilmesini sağlayan bilgi ortam1 (https://sozluk.gov.tr/, 2020).
} 


\section{Robot Gazetecilik}

Gazetecilik mesleğine dair haberin peşinden koşulduğu ve dışarıyla özdeşleşen bir algı söz konusuyken, teknolojinin gelişmesi, kaynakların çeşitlenmesi ve haber formunun değişmesiyle bu algıdan uzaklaşılmıştır (Pınarbaşı ve Astam, 2020: 75). Bu nokta, her geçen gün gelişen yapay zeka teknolojisi haberlere konu olurken, aynı zamanda habercilik alanında da değişim ve dönüşüm yaşanmasına neden olmuştur. Her meslek grubundan robotlar gelişen teknoloji sayesinde gündelik hayatta işleri daha da kolaylaştırmak ve hızlandırmak amacıyla yer almaya başlamıştır. Gelişen yapay zeka teknolojisinin bir ürünü olan robotlar; hizmet, eğitim, sağlık, ticaret, sanat, vb. gibi alanlarda geniş ölçekte varlık göstermektedir.

Robot gazeteciliğin ortaya çıkmasında önemli bir rol oynayan yapay zeka, "akı1ll makineler, özellikle de akıllı bilgisayar programlarını yapma bilim ve mühendisliği” (McCarthy, 2020) olarak tanımlanmaktadır. Yapay zeka, kullanıcıların internetle nasıl etkileşime girdiğini anlamlandırmaya çalışmaktadır ve etkisinin de ilerleyen süreçte artması öngörülmektedir. Yapay zeka, sadece dijital dünyayla değil insanların birbiriyle, çalışmaları ve diğer sosyoekonomik kurumlar aracılığıyla daha iyi ya da kötü etkileşim kurma biçimini büyük ölçüde değiştirme potansiyeline sahiptir (Internet Society, 2020).

Yapay zekâ teknolojisi, haberin paylaşımı ve dolaşımının yanı sıra haberin üretiminde ve yeni iş modellerinin geliştirilmesinde etkindir. Haber kaynaklarının çeşitlenmesi, gelişen internet teknolojileri sayesinde haber ve bilgiye anında ulaşma isteğiyle internet haberciliğinde yapay zeka teknolojisinin kullanılması geleneksel haberci öznesini değiştirmiş "robot" gazeteciyi ortaya çıkarmıştır. Bu habercilik türü, "robot gazeteciliği" (Clerwall, 2014; Dawson, 2010; Van Dalen, 2012), "otomatik gazetecilik", "otomize gazetecilik" ve "algoritmik haberler" (Levy, 2012; Anderson, 2012; Bunz, 2010), "hesaplamalı gazetecilik" (Hamilton ve Turner, 2009), "algoritmik gazetecilik" (Dörr, 2016), "bilgisayarlı gazetecilik", "yazılım türevli gazetecilik" (Clerwall, 2014) olarak da adlandirılmaktadır.

Robotlar "insan eylemlerini gerçekleştirebilen otonom makineler" olarak tanımlanmıştır (Palmerini vd., 2014: 15). Latar'a (2015: 66) göre, yapay zeka teknolojisinin geniş bilgi birikimleriyle dilbilim ve doğa bilimle geliştirilen algoritmaların verileri insan katılımı olmadan, hikaye anlatıcısı olarak saniyenin bir kısmında hikayelere dönüştürmesiyle robot gazeteciliği doğmuştur. Algoritmalar, spor raporları, finansal haberler, hava durumu ve deprem uyarıları gibi yapılandırılmış verilerden haber hikayeleri oluşturabilmekte ve bu verileri otomatik olarak paylaşabilmektedir (Aljazairi, 2016: 5-6). Bir diğer haber türü cinayet haberleridir. Young ve Hermida, Los Angeles Times'1n 2007'de başlattığı cinayet raporu projesini ilk robot gazetecilik örneklerinden biri olarak değerlendirmektedir. Projenin amac1 ise cinayet haberlerinde görülen önyargıları ortadan kaldırmaktır (Graefe, 2016: 21). Bilgisayar algoritmaları yoluyla gazetecilik içeriğinin otonom üretimi olan otomatik gazetecilik, haber kuruluşlarında giderek daha fazla öne çıkmaktadır. Reuters, Forbes, Los Angeles Times, New York Times ve ProPublica algoritmaları içerik üretmek için kullanmaktadır (Graefe, 2016: 9). Son zamanlarda, araştırmacı gazetecilik örneği olarak Ukrayna'da yasa dışı yapılan madenciliğin parçaladığı yerleri bulmak için bir "makine öğrenme modeli" geliştirilmiştir. Bu alanları tespit etmek için yüz binlerce uydu görüntüsü taranmış, yerler belirlenmiş ve duyurulmuştur (Cürgen, 2019).

Algoritmaların gelişmesiyle ortaya çıkan robot gazeteciliğinin tarihi çok eskilere dayanmamaktadır. Yeni nesil gazetecilik türü 2006 yılında Reuters'ın finansal haberleri için algoritmalar kullanacağını açıklamasıyla ortaya çıkmıştır. 2010 yılında dijital medya şirketi Statsheet, Amerikan Kolej Sporları Kurumu (NCAA) basketbol takımların gerçekleştirdiği 15.000 karşılaşmaya dair, 345 web sitesinden alınan bilgilerle algoritmalar oyun istatistiklerini ve bir dizi spor haberini otomatik olarak yazmıştır (Van Dalen, 2012: 648). 2014 yılında Automated Insights şirketi ile ortaklık kurduklarını açıklayan medya kuruluşlarından Associated Press de üç aylık finansal raporlarını otomatik olarak oluşturacağını duyurmuştur. AP'nin editörlerinden Ferrara, 
robot gazeteciler hakkında "Eskiden manuel olarak 300 haber oluştururduk. Şimdi Amerika'nın dört bir yanındaki şirketler için yaklaşık 4400 haber içeriğini otomatik olarak üretebiliyoruz" şeklinde açıklama yapmıştır (Narin, 2015). 2014 yılında Los Angeles'ta meydana gelen bir depremden 3 dakika sonra Los Angeles Times konuyla ilgi otomatik oluşturulan içerikle yayin yapmıştır. Ayrıca gazete genel suç hikayeleri oluşturabilen botlara da sahiptir (Neal, 2014). 2019 yılında ise $\mathrm{BBC}$, seçim sonuçlarını içeren son dakika haberlerini ilk kez bilgisayara yazdırmıştır. Seçim gecesi yayına giren yaklaşık 700 haber otomatik olarak gelen sonuçlara göre oluşturulmuş ve editör tarafından onaylanıp yayına girmiştir. Seçim bölgelerinde oy sayımlarının bitmesine paralel haberler de anında yayınlanmıştır. BBC News Labs editörü McKenzie, "Bu, insanlarla yapamayacağımız türden bir gazetecilik” şeklinde açıklama yapmıştır (Fox, 2019).

Robot gazetecilerin ürettikleri haberlerin güvenirliğini tespit etmeye yönelik Wölker ve Powell (2018: 9-10) tarafindan yürütülen bir araştırmada; robot, insan ve insanın robot yardımıyla hazırladığı içerikler 300 kişiye okutulmuştur. Araştırmanın sonucunda, robot yapımı, insan yapımı ve karma içeriklerin güvenilirlik algılarının eşit derecede olduğu ortaya çıkmıştır. Katılımcılar tarafından spor haberlerindeki robot içerikler insanlar tarafından yapılan haberden önemli ölçüde güvenilir olarak algılanmıştır. Ekonomi haberlerinde ise fark gözlenmemiştir. Robot gazetecilerin profesyonel gazetecilerin yerini alıp alamayacağı tartışılırken diğer yandan da robot gazetecilerin olumsuz özellikleri ön plana çıkarılmaktadır. Robot gazetecilere yönelik yapılan eleştiriler; duygusal bağ kuramadıkları, yaratıcı olamadıkları, anlamlandırma yapamadıkları, saldırgan bir dil kullanabilecekleri, ölüm, şiddetli hastalık ve diğer duygusal olaylarda hassasiyet gösteremeyecekleri, siber saldırıya uğrayabilecekleri, güvenilir olmayan haber kaynaklarını kullanılabilecekleri, reklam ve haber ayrımını yapamayacakları ve etik sorumluluk alamayacakları şeklindedir (Matthews, 2014).

Robot gazeteciliğe yöneltilen eleştiriler doğrultusunda, robot gazetecilerin kolaylaştırıcı ve hızlandırıcı yönü yadsınamamakla birlikte çalışma hayatında profesyonel gazetecilerin de vazgeçilemez olduğu düşünülmektedir. Bu noktada, gazetecilerin robot gazeteciler ile işbirliği içerisinde "makine ile insan" anlayışını benimseyerek alternatif bir bakış açısı geliştirmeleri önem arz etmektedir. Cyborg gazetecilik ${ }^{2}$ olarak açıklanan bu gazetecilik pratiği, teknolojiye karşı/rağmen düşüncesinden sıyrılarak robotlarla çalışan cyborg gazetecilerin yaygınlaşmasiyla hem robotların oluşturabileceği olası tehditler bertaraf edilebilecek hem de nitelikli haberciliğe katk1 sağlanabilecektir (Narin, 2017: 98-99). Karma gazetecilik olarak da adlandırılan bu anlayışın geleceğin gazeteciliği olacağı da öngörülmektedir. Algoritmalar sayesinde rutin işlerin robot gazeteciler tarafindan yapılmasının haber kalitesini artırması, büyük verilerin analizini kolaylaştırması ve yalan haberlerin ${ }^{3}$ (fake news) engellemesi noktasında rol oynayacağ edilmektedir. Karma gazetecilik, robotların insanının yerine geçeceğinin aksine tamamlayacağı görüşüne dayanmaktadır (Journo, 2018).

Robot gazeteciliği maliyet açısından avantaj sağlamaktadır. İnternet haberciliğinde hız çok önemlidir. Belirli sayısal verileri işleyen ve rutin haberlerden otomatik olarak içerik üreten robot gazeteciler, insan iş gücüne daha az ihtiyaç duyulmasını sağlamaktadır. Robot gazetecilik, veri işlemeye dayalı rutin haberler için oldukça uygundur. Rutin haberlerden otomatik bir haber metni üretilebilmekte, zamandan tasarruf sağlanabilmekte ve verimlilik artırılabilmektedir. Bu bağlamda, gazetecilerin günlük rutin haberlerinin robot gazeteciler tarafından yapılması ile ortaya çıkan bu zaman dilimi araştırmacı gazeteciliğin gelişmesine olanak sunmaktadır. Robot gazeteciliğin gazetecilerin, yaratıcılıklarını ve analitik yeteneklerini keşfetmesi noktasında katkı sağlayacağı öngörülmektedir. Robot gazeteciler, dış müdahale olmadı̆̆g sürece kişisel önyargılardan da uzak olmaları açısından gazetecilere göre daha avantajlıdır. Ayrıca algoritmalar sayesinde

\footnotetext{
2 "İnsan ve makine arasındaki sınırları bulanıklaştıran, et ve metal ikiliğini yıkan, sosyal ve kurgusal olarak yaratılmış cinsiyetsiz varl1k" (Haraway 1991; akt. Narin, 2017: 98).

${ }^{3}$ Gerçek olmayan, uydurma haber (https://sozluk.gov.tr).
} 
alışkanlıklarını, ilgi alanlarını ve tercihlerini öğrendikleri okuyucularına kişiselleştirilmiş haberler sunabilmektedir. Finans haberleri açısından ise şirketlerin raporlarını inceleyip kritik veri noktalarını tespit eden robot gazeteciler, saniyeler içinde haber yazıp başlık atabilmektedir.

Robot gazetecilerin, profesyonel gazetecilerin deneyimlerine sahip olmaması bir eksiklik sayılabilir. Robot gazetecilerin ürettikleri haberlerin etik ve hukuki sorumluluğunun net olmamas1 ise bir sorun alanıdır. Algoritmaların kişisel ilgi alanlarına göre haber oluşturması ve bu haberleri sunması da tartışılmaktadır. Temel bilgileri daha hızlı bir şekilde toplayıp işleyebilen araçlar olarak tasarlanan robot gazeteciler, kamuya bilgileri açıklama konusunda avantajlı olsalar da son aşamada editör onayı olmadan haberler yayınlanmamaktadır. Bu noktada, robot gazetecileri manipüle etmeye yönelik girişimler önlenmeye çalışılmaktadır. Yalan haberlerin dolaşımının engellenmesi noktasında robot gazetecilerin yeterli olmadığı dikkate alındığında, editörlerin rolü hala önemini korumaktadır. ${ }^{4}$ Haber kuruluşlarının aynı ekonomik ve teknolojik koşullara sahip olmaması da robot gazeteciliğine adaptasyon sürecini zorlaştırmaktadır. Robot gazeteciler, gazeteciliğin toplumsal işlevinin de geri planda kalmasına, şeffaflık ve fikri haklar gibi yeni etik sorunlarla daha fazla karşılaşılmasına neden olabilir.

\section{Drone Gazeteciliği}

İnsansız Hava Araçları (IHA), literatürde "drone”, "Unmanned Aerial Vehicle (UAV)" ve "Unmanned Aerial Systems (UAS)" olarak adlandırılmaktadır. IHA'ları kavramsallaştırmada sıklıkla "drone" terimine başvurulmaktadır. Drone'lar, aracın içerisinde kendisini yöneten bir pilot ihtiyacı olmadan karadan yönlendirilebilen bir çalışma şekline sahiptir. Drone'lardan gövdesinde bulunan kamera aracılığıyla gökyüzünden görüntü almak amacıyla birçok alanda faydalanılmaya başlanmıştır. "Erkek arı" veya "uzaktan kumandalı uçak" (remotely piloted aircraft (RPAs) olarak açıklanan drone'lar ilk olarak askeri amaçlı kullanılırken, günümüzde ise sivil ve ticari uygulamalar gerçekleştirilmektedir (Goldberg, 2015: 405). Bu yenilik, kısa zamanda haber kuruluşlarının ilgisini çekmiş gazeteciler habere drone'lardan elde ettikleri görselleri eklemeye başlamıştır. Bu pratikler ise "drone gazeteciliği”" olarak adlandırılmaktadır.

Drone gazeteciliği, insansız bir hava aracıyla uzaktan kumanda edilerek kamunun bilgilenmesi gereken bir olay yerinden fotoğraf veya videoyla özel perspektiflerden geleneksel medyayla elde edilmesi zor ya da imkansız olan verilerin toplanmasına yönelik olarak kullanılan bir yöntemdir (Vobic, 2019: 1). Drone teknolojisi daha önce erişilemeyen bilgilere erişim sağlayarak bilgiyi demokratikleştirmesinin yanı sıra havadaki bakış açısıyla veri toplamada duyusal ve mekânsal dökümantasyon olanağı sağlamaktadır. Güvenli, daha uygun maliyetli, erişilebilir ve insanlı veya analog uzaktan kumandalı uçaklara alternatif olarak kullanımı daha kolay yeni hikaye anlatım olanakları da oluşturmaktadır (Kreimer, 2018: 91).

Drone gazeteciliği, veri toplama aşamasında maliyet açısından kolaylık sunmakta, gazetecilerin güvenliklerine katkı sağlamakta, genişletilmiş hikaye olanağı tanımakta, yenilikçi teknolojilerle de entegrasyonu gerçekleştirmektedir (Ntalakas vd., 2017: 197). Drone gazeteciliği ayrıca haber toplama amaçlı hava fotoğrafçılığ 1 alanı olarak görülmekte, 21. yüzyılın foto muhabirliği adlandırılmasıyla da anılmaktadır. Drone gazeteciliğini diğer uygulamalardan ayıran yönün ifade özgürlüğü ve video veri/bilgilerini elde etmek için iletişim teknolojisine erişim ve kullanma hakk1 olduğu düşünülmektedir (Goldberg, 2016: 222-224). Dünya çapında haber kuruluşlarından CNN, BBC, AP, Reuters, AFP, Itar-Tass, Xin-Hua ve diğerleri drone kullanımını yaygınlaştırmaktadırlar. Drone kullanımının Türkiye'deki kurumsal öncülüğü haber ajansları ve TRT tarafindan yapılmaktadır (Şahin, 2018b: 184).

Drone'ların habercilik alanında kullanımı haber toplama esnasında gazetecilerin güvenliğini tehdit edebilecek durumlarda daha çok doğal afet bölgelerinde tercih edildiği

4 Assoaciated Press 2015'te ilk kez haber otomasyon editörü adını verdiği bir kadro açmıştır (Fındık, 2016). 
görülmektedir. Yangın, deprem, çı̆̆ düşmesi ve sel baskını gibi doğal afetlerin yaşandığı bölgelerden bilgi, belge ve görüntü elde edilmesinde yaygın olarak kullanılan drone'lar savaş ve kaza gibi yerleşim yerinin dışında gerçekleşen ve ulaşımın mümkün olmadığı alanlarda güncel bilgi aktarımında da tercih edilmektedir. Ayrıca doğa, çevre, turizm, manzara, yapılar vb., belgesel konulardaki haberlerde drone çekimleri yapılmaktadır. Toplumsal olaylarda, miting, gösteri, spor etkinlikleri ve konser alanlarında geniş katılımın söz konusu olduğu durumlarda ise drone'lar hızlı görüntü alımı noktasında işlevseldir. Yurttaş gazeteciliği açısından da drone kullanımının haberlere çeşitlilik sağlamasının yanı sıra farklı bir bakış açısı kazandırdığı ve demokratik bir medya ortamının oluşmasına da katkı sağladığı ifade edilebilir (Şahin, 2018a: 263, Kavaklı, 2018: 161).

Haber toplama süreçlerinde drone kullanılabilmesi için bir takım yasal sorumlulukların yerine getirilmesi gerekmektedir. Drone kullanmak isteyen bireyler yetkili kuruluşlardan İHA ehliyeti almak zorundadır. Bu ehliyete sahip olan kişiler içinde birtakım sınırlamalar söz konusudur. Drone uçuşu gerçekleştirmek isteyen 500 gr. üstü İHA sahibi kişi veya ticari kuruluşların Sivil Havacılık Genel Müdürlüğü kayıt sistemi üzerinden araçlarını kayıt ettirmeleri ve izin alarak uçuş yapmaları gerekmektedir (SHGM, 2020).

Drone gazeteciliğinin habercilik pratiklerine katkısı genel olarak üç temel düzeyde gerçekleşmektedir:

Maliyet ve hız: Drone'lar haber toplama süreçlerine dahil olmadan önce medya kuruluşları gökyüzünden görüntü alınmasının gerekli olduğu durumlarda özel helikopter uçuşu gerçekleştirken, kısa süreli de olsa bu uçuş oldukça maliyetli ve zaman planlamasını gerektirmeydi. $\mathrm{Bu}$ geleneksel yönteme karşılık drone'lar aracılığıyla veri elde edilmesi ise maliyet ve hız açısından avantaj sağlamıştır.

Can güvenliği ve ulaşım: Gazetecilerin can güvenliğinin tehlikede olacağı olaylarda drone'ların kullanılması güvenlik tehdidini büyük ölçüde ortadan kaldırmıştır. Aynı zamanda geleneksel yöntem ve araçlarla ulaşmalarının mümkün olmadığı alanlardan enformasyon almalarının da önü açılmıştır.

Haber içeriğinin zenginleşmesi: Gökyüzünden panoramik bir bakışla ve farklı perspektiflerle görüntü aktarımının gerçekleştirilmesi haber içeriğini zenginleştirmektedir. Drone'lar yeni hikâye anlatım yolları oluşturarak da haber değer ölçütlerinden olan "yenilik" değerine katkı sağlamıştır.

Drone gazeteciliğinin gelişmesine yönelik akademi ve medya alanında uyumlaşma süreci halen devam etmektedir. Dünya'da ve Türkiye'de gazetecileri bu konuda nitelikli olarak yetiştirmek amacıyla "drone gazeteciliğì" alanında dersler açılmıştır. Medya kuruluşları ise bu alanda olanakları ve yayın politikaları doğrultusunda hem araçsal hem de niteliksel yatırımlarını sürdürmektedir. Drone gazeteciliğinin gelişim süreci ve habercilik alanına katkılarının yanı sıra yasal ve etik boşluklar oluşturduğu da göz ardı edilmemelidir. Drone'ların görüntüleme alanlarının ve erişim olanaklarının ucunun açık olması ulusal güvenlik, kamu güvenliği ve özel yaşamın gizliliği noktasında risk unsuru oluşturması da ihtimal dahilindedir.

\section{Artırılmış Gerçeklik Gazeteciliği}

Bilişim alanında gerçekleştirilen çalışmalardan olan gerçeklik çalışmaları, hayatın birçok alanında gün geçtikçe yer almaya başlamıştır. Sanal gerçeklik (Virtual Reality) ve artırılmış gerçeklik (Augmented Reality) birbiri yerine kullanılmaktadır ancak ikisinin arasında farklılıklar söz konusudur.

Sanal gerçeklik uygulamalarında kullanıcılar bir bilgisayar tarafından oluşturulan tamamıyla sanal bir ortam içine alınır. Donanım yardımlarıyla kullanıcılara belirli alan içinde hareket özgürlüğü sağlanarak, sunulan içerikleri deneyimleme ve daldırma olarak da adlandırılan içine girebilme olanağı tanınmıştır. $\mathrm{Bu}$ ortamda kullanıcılar, hareket edebilmekte, sesleri 
işitebilmekte ve tepki verebilmektedir. Ayrıca sanal gerçeklik uygulamasında el kontrolünü sağlayan cihazlar da kullanılabilmektedir (Gürcan, 2018: 129). Sanal gerçeklik ve artırılmış gerçeklik uygulamalarındaki fark ise ortamdan kaynaklıdır. Sanal gerçeklik uygulamalarında kullanılan sanal ortamlarda kullanıcılar dünya ile ilişkisini koparmaktadır. Artırılmış gerçeklik uygulamasında ise kullanıcıların dünya ile bağlantısı devam etmekte, gerçek ve sanal nesnelerin birlikte tek bir ortamda algılanmasına yönelik bir uygulama gerçekleştirilmektedir.

Artırılmış gerçeklik, gerçek dünya görüntüleri ile sanal olarak varolmuş nesnelerin birbirine eklemlenmesiyle oluşan zenginleştirilmiş bir ortamdır. Sanal ve gerçek nesnelerin eş zamanlı birlikteliğini sağlayan bu ortamlar gerçek ve sanal yaşamı da iç içe geçirmektedir. Artırılmış gerçeklik, bilgisayar tarafından üretilen ses, görüntü, animasyon, hologram gibi dijital unsurları akıllı telefon, tablet ve sanal gerçeklik gözlükleri aracılığıyla bulunulan ortamın üzerine gerçek zamanlı olarak yerleştirerek yeni bir algı ortamı oluşturmaktadır. Böylelikle gerçek hayatta fiziksel olarak yerleştirilmesinin mümkün olmadığı nesneler ve olgular algılanabilir boyuta dönüşmektedir. Artırılmış gerçeklikte, kullanıcılar gerçek dünyayı yaşarken uygulamaya eklenen içerik ile etkileşime girmektedir. 2016 y1lında Pokemon ${ }^{5}$ 'un akıllı cihaz uyarlamasıyla dünya genelinde tecrübe edilen Pokemon Go örneği artırılmış gerçeklik örneklerindendir. Artırılmış gerçeklik genel bir ifadeyle bilgisayar ortamında oluşturulan materyallerin bireylerin gerçek dünyayı algılamalarına yardımcı olan geniş açılı bir teknoloji olarak açıklanabilir (Abdüsselam ve Karal, 2012: 171; Bingöl, 2018: 46; Gürcan, 2018: 130). Azuma vd.'ye (2001: 34) göre, artırılmış gerçekliğin üç özelliği vardır; gerçek ve sanal nesneler gerçek bir ortamda birleşmekte ve tamamlanmaktadır, etkileşimli ve gerçek zamanlı çalışarak hem gerçek hem de sanal nesneler birbirine hizalanmaktadır.

Artırılmış gerçeklik uygulamaları laboratuvar deneylerinden sonra askeri, endüstriyel ve bilimsel kullanıcıların ihtiyaçlarını karşılamaya yönelik olarak gerekli bütçe ile uyumlaştırılarak kullanılmaya başlanılmıştır (Peddie, 2017: 11). Artırılmış gerçeklik çalışmalarının 2000'li y1llardaki gelişim göstermesi ise teknolojinin ucuzlamasına ve mobil telefonlar/tabletler gibi çeşitli cihazların yaygınlaşmasına bağlanabilir (Yöndem ve Karadağ, 2019: 25). Günümüzde ise artırılmış gerçeklik uygulamalarında yeni iletişim ortamlarında sunulan deneyimlerin çeşitlenmesiyle birlikte eğlence, eğitim, mimari, tasarım, spor, sağlık alanlarına doğru bir yayılım izlenmektedir. Dijital dönüşümün bir sonucu olarak gazetecilik alanında da artırılmış gerçeklik ile ilgili gelişmeler yaşanmaya başlamıştır. Söz konusu bu uygulamalar "artırılmış gerçeklik gazeteciliği” olarak adlandirılmaktadır.

Artırılmış gerçeklik gazetecilik kavramı "sanal dünya ile gerçek dünya arasında bir iletişim kurma sanatı" olarak tanımlanabilir. Bu sanat, akıllı cihazların fiziksel olarak varolan ve günlük olarak kullandığımız kimi nesnelere yöneltilmesiyle beraber, bireylere o nesne hakkında bilgiler sunma şeklinde gerçekleşmektedir (Alp ve Turan, 2018: 7). Gazetecilik alanında artırılmış gerçeklik teknolojisinin kullanımı ilk kez Columbia Üniversitesi'nde kurulan Yeni Medya Merkezi tarafından gerçekleştirilmiştir. Merkez, 1997 yılında New York'da Aziz Patrick Günü'nde LGBTİ+ bireylerin törene dahil olamamaları nedeniyle yaptıkları protesto sirasında polis tarafindan tutuklanmalarını izleyicilere 360 derece video çekimi ile aktarmıştır. Bu ilk deneme sadece güncel olayların aktarımıyla sınırlı kalmayıp, 1968 yılında Columbia Üniversitesi'nde gerçekleşen öğrenci isyanına ait gerçek görüntüler, videolar ve ses kayıtları kullanılarak artırılmış gerçeklik teknolojisiyle yeniden canlandırılmıştır (Pérez Seijo, 2017: 114).

Günümüzde, artırılmış gerçeklik gazeteciliğinin ivme kazandığı gözlenmektedir. Dünya çapında ilk kez İrlanda'da yerel yayın yapan bir gazete olan Metro Dublin kullanıcılarına hem haberleri hem de reklamları artırılmış gerçeklik uygulamasına yer vererek etkileşimli olarak

\footnotetext{
${ }^{5}$ Satoshi Tajiri tarafından geliştirilen hayali canlıları konu alan oyun, anime, manga ve kart oyunu serisidir (https://tr.wikipedia.org/wiki/Pok\%C3\%A9mon).
} 
sunmuştur (Çetin, 2018: 54). Türkiye'de yazılı basında artırılmış gerçeklik ise ilk kez Milliyet gazetesi tarafindan uygulanmıştır. Gazete, okuyucularına akıllı cihazlarına yükleyebilecekleri Blippar uygulaması ile interaktif bir ortam sağlayarak haberle ilgili fotoğraf galerilerine, anketlere, videolara, markalara ait kampanya ve reklamlara ulaşmalarını sağlamıştır (Milliyet, 25 Eylül 2013).

Çevrimiçi ve çevrimdışı ortamları bir noktada birleştiren artırılmış gerçeklik gazeteciliği, medyanın iletişim boyutunu etkileşimselliği de içinde barındıran bir yapıya büründürmektedir. Yeni teknolojilerin medya alanına entegrasyonu içeriklerin ve pratiklerin zenginleștiği yeni bir gazetecilik formunun oluşmasına katkı sağlamaktadır. Hareketli görseller, QR kod uygulamaları, artırılmış gerçeklik teknolojisinden yararlanılarak gerçekleştirilen haber sunumları, akıllı cihazların yazılı basında yer alan metinlere tutulması yoluyla haberlerin interaktif bir yapıya dönüşmesiyle haberi alımlayan bireylerin içeriğe dahil olmaları ve belirli ölçüde katılım göstermeleri artırılmış gerçekliğin gazetecilik alanına yaptığı katkılardandır.

Alanda bu uygulamalar "sürükleyici gazetecilik" olarak da adlandırılmaktadır. Perez Seijo'ya (2017:118) göre, sürükleyici gazetecilik habere konu edilen olaylar ve durumlar hakkında birinci şahıs deneyimi sunmaktadır. Duyguları hissedebildiği ve içgüdüsel bedensel refleksler gösterebildiği için özne bilginin aktörü olmaktadır. Sürükleyici teknoloji, hikaye anlatımı ve raporlamayı yeniden şekillendirme yeteneğine sahiptir. Bireyleri bugün dünyayı şekillendiren büyük sorunların merkezine koymak geleneksel gazetecilikten daha etkili ve akılda kalıcıdır. Bu yüzden New York Times ve The Guardian gibi haber kuruluşları, izleyicilerle empati kurmak için sanal gerçeklik, 360 derecelik videolar ve artırılmış gerçeklik teknolojilerini kullanmaktadır. Baskı satışlarındaki düşüşün ortasında bu teknolojiler, yeni kitlelere hitap eden ve mevcut okuyucularla ilişkileri güçlendiren başlıkların güncel ve ilgili kalmasına da yardımcı olabilmektedir. Artırılmış gerçeklik, okuyucuya gerçek bir bağlam duygusu sunarak ve izleyicinin kavraması zor olan konuları gündeme getirebilmektedir (Rogers, 2020).

Pavlik'e (2013: 27-43) göre, sürükleyici gazetecilik örneklerinde kullanılan tüm yönlü kameralar geleneksel medyada kullanılan video teknolojilerinin birden fazla kamerayla bile yakalayamadıkları 360 derecelik görüş alanıyla dinamik olarak olayları yakalamalarını sağlamakta ve izleyicilere olay yerinde oldukları hissini veren ses ortamlarını oluşturmaktadır. Tüm yönlü kameralar izleyicilere, haberi tecrübe etmelerini sağlayarak kontrol imkânı da sunmaktadır. Bu durum ise haberin güvenilirliğini artırmaktadır. Pavlik, ayrıca haberde yalnızca tek bir perspektif sunmanın gerçekliğin sadece belirli bir kısmını yansıtacağını objektiflik ve gerçeklik noktasında eksik kalacağını vurgulamaktadır. Yapı ve bağlamın online, multimedya ve interaktif ortamlarda hikaye anlatımlarıyla aktarılması, okuyucunun haberi aktaran kişinin önyargısından kurtulup hikayeyi çevreleyen olaylar ve bağlamı dengeli bir şekilde alımlamasının önünü açmaktadır. Bilgi ve haber tüketiminde bireylerin büyük ölçüde çevrimiçi platformlara yöneldiği göz önüne alındığında, artırılmış gerçeklik gazeteciliği hem yazılı hem de görsel işitsel medya için okuyucu ve izleyiciyle etkileşime geçmek, içerikleri çekici kılmak ve farklı perspektifler sunmak adına yeni bir yol oluşturmaktadır. Bu teknolojik imkan, çevrimiçi ve çevrimdışı ortamları bir araya getirerek basılı yayıncılığın tek taraflı aktarımını çift yönlü bir etkileşime geçirmek için bir alternatif sunsa da kullanıcının varlık duygusunun ve içeriğe dahil olmasının sınırlı olduğu göz ardı edilmemelidir. Artırılmış gerçeklik ve sürükleyici gazetecilik örneklerinin tüm bireyleri kapsayıcı bir şekle dönüşmesi için birtakım oluşumlar henüz tamamlanmamışıı. Bu pratiklerin yaygınlaşması için gazetecilerin teknolojiyi kullanma, içerik oluşturma modellerinin geliştirilmesi gerekirken, haber kuruluşlarının da artırılmış gerçeklik teknolojisine yapacakları yatırımlar için yeterli bir bütçe ayırmaları gerekmektedir. Diğer bir nokta ise kapsayıcılı̆̆ 1 sağlamak adına okuyucu/izleyici veya kullanıcıların sahip oldukları teknolojiyi kullanım becerilerinin geliştirilmesine yönelik gerekliliktir. 


\section{Blokzincir Gazeteciliği}

İnternet üzerinde bir veri tabanı olan blokzincir teknolojisi, kripto para birimi Bitcoin ile ilk kez duyulmaya başlanmıştır. Banka ya da merkezi bir otorite olmadan internet üzerinden para aktarılmasına olanak sağlayan Bitcoin, 2009 yılında Satoshi Nakamoto kimliğini kullanan bir kişi ya da grup tarafindan geliştirilmiş, blokzincir veri tabanı ile tasarlanmış ve dağıtılmıştır (Ignota, 2020). Bir bilgisayar ağı arasında paylaşılan veri tabanı olan blokzincire, yeni bir kayıt eklendikten sonra değiştirilmesi çok güçtür. Veri tabanındaki kopyaların aynı olduğunu kontrol etmek amacıyla ağ sürekli olarak denetim yapmaktadır. Bir veri tabanı üç aşamadan oluşmaktadır; ilk aşama herhangi bir bilginin olduğu kayıt, ikinci aşama bir grup kayıttan oluşan blok, üçüncü aşama ise bütün blokların birbirine bağlı olduğu zincirdir (Murray, 2018). Diğer bir deyişle, kayıtlar bloklar halinde bir araya getirilir ve birbiri ardına zincire eklenir. Depolanan verilerin güvenlik ve izleme işlemleri yapılır, değişmeyen salt eklenti bir veritabanı olan blokzincirde, zincirlerin bir karma oluşturarak eklemlenmesi güvenirliği arttırmaktadır. Zincire dahil olan kişi sayısının artması da güvenilirliğe katkı sağlamaktadır.

Blokzincirler, para birimini desteklemek amacıyla kullanılsa da zamanla diğer alanlarda da kullanımı keşfedilmeye başlanmıştır. Olası kullanım alanları arasında, bankacılık, kripto para, tedarik zinciri, sağlı hizmetleri, oy verme işlemi ve emlak kayıtları yer almaktadır. Finans üzerine temellenen bu sistem gazetecilik alanında da kullanılmaya başlanmıştır. Gazetecilik uygulamalarındaki sorun alanlarının çözüme kavuşacağına yönelik iyimser düşünceyle de deneyimlenmektedir. Bernat Ivancsics, (2019) medya kuruluşları için kullanım alanlarını üç temel alanda gruplandırmıştır:

- Editoryal ve reklamcılık için denetlenebilir, doğrulanabilir veri tabanı çözümleri,

- Kripto para birimine dayalı iş modelleri,

- Blokzincir tabanlı dosya sistemlerinde korunan genel verilere erişim.

Blokzincirler, gazetecilik alanında bir hikâyenin kökeni hakkındaki verilerin depolanması, denetlenmesi ve haberlerin yayınlanma zamanında kullanılabilmektedir. Önemli verilerin güvenli kaydedilmesine olanak sağlayabilen blokzincir tabanlı kayıtlar, güvenilir reklam verenleri, reklam içeriğini veya zararlı reklamları filtreleyebilmektedir. Veri tabanı çözümleri medya kuruluşları arasında ve medya ile kamu arasında güven oluşturmak için kullanılabilmektedir (Ivancsics, 2019).

2016 yılında Blokzincir tabanlı Civil isimli bir medya kuruluşu oluşturulmuştur. "Reklamlardan, yalan haberlerden ve dış etkenlerden arınmış gazetecilik için kendi kendini sürdüren küresel bir pazar" hedefiyle kurulan Civil'de, CVL adlı yeni bir blokzincir tabanlı jetonla işlemler gerçekleştirilmiştir (Keefe, 2019). Civil CEO'su Schiller, medya endüstrisinde kamu güvenine ve finansal sürdürülebilirlik krizine dikkat çekmiştir. Schiller, blokzincirin merkezi otoritelere olan ihtiyacı ortadan kaldırması, verileri değiştirmenin güçlügü ve habere güveni sağlayacak özellikleri nedeniyle krizi bitirebileceğini ve habere olan güvenin yeniden kazanılacağını savunmuştur (Li, 2018). Ancak Civil daha sonra Ethereum üzerinde kimlik çözümleri oluşturmak için ConsenSys'e katılmıştır (Civil, 2020). Blokzincir sistemi üzerine kurulan diğer medya kurumları Po.et, AdChain, SocialFlow'tur (Ivancsics, 2019). Türkiye'de ise CoinTürk, Blokzincir teknolojisini kurumsal olarak kullanan medya kuruluşları arasında yer almaktadır (CoinTürk, 2018).

Blokzincir gazeteciliğinin, çevrimiçi ve çevrimdışı haberciliğin mücadele etmekte zorlandığı yalan haberlerin kaynağı ile yayılımının tespiti noktasında kolaylık sağlayacağı düşünülmektedir. Yoğun bilgi akışının arasında yalan haber tespiti ve doğru bilginin ayırt edilebilir olması oldukça önemlidir. Daha güvenilir bir bilgi ağı oluşturmayı amaçlayan bu gazetecilik türü özellikle finans gazeteciliği açısından büyük bir potansiyele sahiptir. Yeni bir iş modeli sunan bu gazetecilik türünün, habere ve gazeteciye olan güvenin yeniden tesis edilmesine ve daha kaliteli

Turkish Studies - Social, 15(5) 
bilginin yayılımına olanak sunması öngörülmektedir. Maliyetli işlemlerin daha ucuz ve kolay yapılması ve güvenlik seviyesinin yüksek olması nedeniyle gelecek vadeden blokzincirin dönüştüreceği teknolojiye uyum sağlayabilmek için kurumların yatırımları devam etmektedir.

\section{Sonuç}

Yüzyıllar boyunca bireylerin haber alma ve haber verme ihtiyaçları içinde bulundukları çağın teknik olanakları dahilinde gerçekleşmiştir. Gelişen iletişim teknolojileri sayesinde haber toplama süreci ve habere ulaşma yolları da gün geçtikçe çeşitlenmektedir. Geleneksel medyanın kullanılmasıyla başlayan gazeteciler tarafından haber ulaştırma süreci, yeni iletișim ortamlarının gelişmesiyle dijital platformlarda da sürdürülmektedir. Teknolojik gelişmelerin gazetecilik alanına uyarlanmasıyla birlikte yeni nesil gazetecilik türleri oluşmuş, gazeteciliğin, gazetecinin ve haberin sınır alanları genişlemiş̦tir. Yeni nesil gazetecilik haber toplama, yayınlama ve alımlama süreçlerine katkı sağlarken, aynı zamanda sorun alanları da oluşturmuştur.

Yeni nesil gazetecilik gazeteci, haber ve okuyucu/izleyici açısından değerlendirildiğinde hem özgürleşim hem de sınırlayıcı alanlar sunmaktadır. Gazetecilik uygulamaları açısından özgürleşim ve sınırlayıcı alanlara odaklanıldığında; tek yönlü ve dikey olarak ele alınan haberin farklılaştı̆̆ı, otomatikleşen içeriklerle zaman tasarrufu elde edildiği ve haber toplama sürecindeki maliyetin azaldı $\breve{g}$ ifade edilebilir. Yeni nesil gazetecilikle birlikte haber; hız, çeşitlilik, güncellik ve yenilik kazanmıştır. Metin, fotoğraf ve video gibi haber öğelerinin içeriği farklı tekniklerle zenginleştirilmiştir. Arka planı destekleyici öğelerin kullanılması ise haberin bağlamından kopartılmamasını sağlamıştır. Farklı teknik ve yolların kullanılması haberin çok yönlü bir bakış açısı sunmasını olanaklı kılmıştır.

Yeni nesil gazetecilik türlerinden biri olan drone gazeteciliğiyle, gazetecilerin can güvenliğinin olmadığı olaylarda kurtarıcı uygulamalar geliştirilmiş, ulaşmalarının mümkün olmadığı mekânsal sınırlıklar bulunan alanlara erişim imkanı tanınmıştır. Veri gazeteciliği, yeni uzmanlık alanlarından çevre, barış ve hak gazeteciliği gibi uygulamaları ortaya çıkarmış ve araştırmacı gazeteciliğin gelişmesine olanak sunmuştur. Robot gazeteciliğin, alanda işsizliğe yol açabileceğine dair görüşler bulunsa da haber otomasyon editörü adı verilen yeni bir kadronun oluştuğu ve editörlerin rolünün hala önemini koruduğu gözlenmiştir. Haber kuruluşlarının teknolojik gelişmeleri yakalayabilmeleri için teknik ve nitelik olarak yatırım yapmaları ise maliyeti artırmıştır. Kuruluşların aynı ekonomik ve teknolojik koşullara sahip olmaması da yeni nesil gazetecilik türlerine adaptasyon sürecini zorlaştırmıştır. Gazetecilik sektöründe dönüşümün devam ettiği ve bu süreçte gazetecilik uygulamalarının farklılaşması nedeniyle gazetecilerin teknoloji kullanma becerilerini geliştirmeleri de günümüz gerekliliklerindendir.

Okuyucu/izleyici açısından incelendiğinde ise yeni nesil gazetecilik etkileşim imkanı tanıyarak interaktifliği destekleyen bir yapı sergilemektedir. Artırılmış gerçeklik gazeteciliği haber olaylarında duygu aktarımının yoğunlaşmasına, okuyucu/izleyicilerin habere dahil olmalarına, uygun durumlarda hikayeye katılmalarına ve haberle aralarındaki bağın kuvvetlenmesine zemin oluşturmuştur. Robot gazetecilik, okuyucu/izleyicilerin alışkanlıklarına, ilgi alanlarına ve tercihlerine göre kişiselleştirilmiş haberler sunabilmektedir. Bu durumun yankı odası etkisi oluşturabileceği, haber metinlerinin tek tipleşerek okuyucu/izleyicilerin karşııt görüşleri içeren haber metinlerinden uzaklaş1labileceğine dair yürütülen tartışmalar mevcuttur. Blokzincir gazeteciliğinin ise yalan haberin artması nedeniyle medyaya ve habere karş1 oluşan şüphenin ortadan kalkmasında ve güvenin yeniden inşa edilmesinde etkili olması beklenilmektedir.

Geniş bir çerçeveden bakıldığında ise her teknolojik gelişmede olduğu gibi yeni nesil gazetecilikte de okuyucu/izleyiciler için dijital uçurum farkındalığı ve dijital okuryazarlı̆̆ın önemi yadsınamamaktadır. Bu değerlendirmelerin yanı sıra yeni nesil gazetecilik teknoloji kullanımından kaynaklı yasal sorumlulukları da beraberinde getirmiş; ulusal güvenlik, kamu güvenliği ve özel yaşamın gizliliği noktasında ise sorun alanları oluşturmuştur. Aynı zamanda etik boyutlarının ele 
alındığ 1 güncel tartışmaları da başlatmıştır. Sonuç olarak, yeni nesil gazetecilik uygulamalarında tespit edilen sorun alanlarının küresel ölçekte ve evrensel boyutta olması geliştirilecek olan çözüm önerilerinin, özel yaşamın gizliliği ile kamunun bilgilenme hakkı arasındaki dengeyi koruması açısından önem arz etmektedir.

\section{Kaynakça}

Abdüsselam, M. S. ve Karal, H., (2012). Fizik öğretiminde artırılmış gerçeklik ortamlarının öğrenci akademik başarısı üzerine etkisi: 11. sınıf manyetizma konusu örneği, Eğitim ve Öğretim Araştırmaları Dergisi, 1 (4), 170-181.

Açık Veri ve Veri Gazeteciliği Türkiye (2012). Hakkında, http://www.verigazeteciligi.com/. Erişim Tarihi: 26.06.2020.

Aljazairi, S. (2016). Robot Journalism: Threat or an Opportunity, Örebro University School of Humanities, Education and Social Sciences MA Thesis.

Alp, H. ve Turan, E., (2018). Gelenekselden Dijitale Medyanın Dönüşümü Çerçevesinde CNNTÜRK ve NTV İnternet Sitelerinin Karşılaştırmalı Analizi, Turkish Studies, 13 (29), $1-18$.

Anderson, C. W., (2013). Towards a sociology of computational and algorithmic journalism, New Media \& Society, 15(7), 1005-1021. http://dx.doi.org/10.1177/1461444812465137

Azuma, R., Baillot, Y., Behringer, R. Julier, S. ve Blair M., (2001). Recent advances in augmented reality, IEEE Computer Graphics and Applications, 21(6), 34-47.

Bingöl, B. (2018). Yeni bir yaşam biçimi artırılmış gerçeklik (AG), Üsküdar Üniversitesi İletişim Fakültesi Akademik Dergisi Etkileşim, 1(1), 44-55.

Bradshaw, P. (2012). What is data journalism?, https://datajournalism.com/read/handbook/one/introduction/what-is-data-journalism. Erişim Tarihi: 09.06.2020.

Bunz, M. (2010). In the US, algorithms are already reporting the news, https://www.theguardian.com/media/pda/2010/mar/30/digital-media-algorithms-reportingjournalism. Erişim Tarihi: 06.06.2020.

Civil (2020). Ending the civil journey, https://civil.co/ Erişim Tarihi: 23.06.2020.

Clerwall, C. (2014). Enter the robot journalist, Journalism Practice, 8(5), 519-531. http://dx.doi.org/10.1080/17512786.2014.883116

CoinTürk (2018). Proofstack ve CoinTürk blockchain işbirliği, https://coin-turk.com/proofstack-vecointurk-blockchain-isbirligi. Erişim Tarihi: 26.06.2020.

Cox, M. ve Ellsworth, D. (1997). Application-controlled demand paging for out-of-core visualization, IEEE Xplore, 235-244.

Çetin, B. (2018). "Geleceğin Teknolojileri ve Gazetecilik Mesleği Üzerine Etkileri: Büyük Veri, Veri Gazeteciliği, Yeni Yaklaşımlar”, Olcay Uçak (ed), Dijital Medya ve Gazetecilik, Eğitim Kitabevi, 32-61.

Cürgen, E. (2019). Gazetecilikte yapay zekâ kullanımının en beğenilen 10 yolu, https://journo.com.tr/gazetecilik-yapay-zeka. Erişim Tarihi: 16.06.2020. 


Dağ, $\quad$ P. (2016). "Veri okuryazarlı̆̆ 1 el kitabı",
https://www.academia.edu/34442143/Veri_Okuryazarl\%C4\%B1\%C4\%9F\%C4\%B1_El_K itab\%C4\%B1. Erişim Tarihi: 16.06.2020.

Dawson, R. (2010). The rise of robot journalists, https://rossdawson.com/blog/the_rise_of_rob/. Erişim Tarihi: 18.06.2020.

Diebold, F. X., (2012). On the Origin(s) and Development of the Term Big Data, https://papers.ssrn.com/sol3/papers.cfm?abstract_id=2152421. Erişim Tarihi: 25.06.2020.

Dörr, K. N. (2016). Mapping the field of algorithmic journalism, Dijital Journalism, 4(6), 700-722. http://dx.doi.org/10.1080/21670811.2015.1096748

Fox, C. (2019). General election 2019: How computers wrote BBC election result stories, https://www.bbc.com/news/technology-50779761. Erişim Tarihi: 15.06.2020.

Goldberg, D. (2016). "Droning on About Journalism: Remotely Piloted Aircraft and Newsgathering", Ales Zavrsnik (ed), Drones and Unmanned Aerial Systems. Legal and Social Implications for Security and Surveillance, Springer. s.217-242.

Goldberg, D. (2015). Dronalism: journalism, remotely piloted aircraft, law and regulation, FIU Law Review, 10(2), 405-434.

Graefe, A. (2016). Guide to automated journalism, file://C:/Users/lenovo/Downloads/GuideToAJ\%20(1).pdf. Erişim Tarihi: 15.06.2020.

Gray, J., Chambers, L., ve Bounegru, L., (2012). The data journalism handbook: how journalists can use data to improve the news, O'Reilly Media.

Gürcan, H. İ. (2018). Sanal Sağlık İletişimi: Sanal Gerçeklik ve Sağlık İletişiminde Sanal Uygulamalar, Sağlık İletişimi Sempozyumu Bildiri Kitabı, 126-140, 30-31 Ekim Alanya.

Gürsakal, N. (2014). Büyük Veri, Dora Yayınları.

Fındık, H. K. (2016) Robot gazetecilik: Gazetecilik için tehdit mi yoksa firsat mı?, https://digitalage.com.tr/robot-gazetecilik-gazetecilik-icin-tehdit-mi-yoksa-firsat$\mathrm{mi} /$.Erişim Tarihi: 26.06.2020.

Hamilton, J. T. ve Turner, F. (2009). Accountability through algorithm: developing the field of computational journalism, https://web.stanford.edu/ fturner/Hamilton\%20Turner\%20Acc\%20by\%20Alg\%20Final.pd f. Erişim Tarihi: 18.06.2020

Howard, A. B. (2014). The art and science of data-driven journalism, file://C:/Users/lenovo/Downloads/GuideToAJ\%20(1).pdf. Erişim Tarihi: 20.06.2020.

Ignota (2020). The white paper, https://ignota.org/products/the-white-paper. Erişim Tarihi: 15.06.2020.

Internet Society (2020), Artificial intelligence (AI), https://www.internetsociety.org/issues/ai/?gclid=CjwKCAjw88v3BRBFEiwApwLeveQoz ZNwOuL8wKDgOcTLLZPN5zGXXlr7g_KLxvyIPtocCSVd6QFoBoCgMYQAvD_BwE. Erişim Tarihi: 08.06.2020.

Ivancsics, B. (2019). Blockchain in journalism, https://www.cjr.org/tow_center_reports/blockchain-in-journalism.php. Erişim Tarihi: 16.06.2020.

Journo (2018). Robotun yaptı̆̆ 1 haber insanın yaptığı haber kadar güvenilir bulundu, https://journo.com.tr/robot-haber-karma-gazetecilik. Erişim Tarihi: 25.06.2020. 
Kavaklı, N. (2018). Drone'ların gazetecilikte kullanımı: drone haberciliğinin olanakları, zorlukları ve sinırları, Erciyes Illetişim Dergisi, 5(3), 160-172.

Keefe, J. (2019). How to buy into journalism's blockchain future (in only 44 steps), https://www.niemanlab.org/2019/03/how-to-buy-into-journalisms-blockchain-future-butthis-time-in-only-33-steps/. Erişim Tarihi: 23.06.2020.

Kreimer, B. (2018). "Drone Journalism: Storytelling from a New Perspective", Oliver Hahn ve Florian Stalph (ed.), Digital Investigative Journalism, Springer International Publishing, 91-102.

Latar, N. L. (2015). The robot journalist in the age of social physics: the end of human journalism? G. Einav içinde, The New World of Transitioned Media Digital Realignment and Industry, Springer International Publishing, 65-80.

Levy, S. (2012). Can an algorithm write a better news story than a human reporter?, https://www.wired.com/2012/04/can-an-algorithm-write-a-better-news-story-than-ahuman-reporter/. Erişim Tarihi: 16.06.2020.

Lewis, S. C. ve Westlund, O. (2015). Big Data and Journalism. Epistemology, expertise, economics, and ethics, Digital Journalism, 3 (3), 447-466.

Li, Mia Shuang (2018).What can blockchain actually do for journalism?, https://www.cjr.org/tow_center/what-can-blockchain-actually-do-for-journalism.php.

Erişim Tarihi: 20.06.2020.

Manovich, L. (2011). Trending: The promises and the challenges of big social data, http://manovich.net/content/04-projects/067-trending-the-promises-and-the-challenges-ofbig-social-data/64-article-2011.pdf. Erişim Tarihi: 26.06.2020.

Matthews, K. (2014). 10 reasons why robot journalism can't top the real thing, https://muckrack.com/blog/2014/08/19/10-reasons-why-robot-journalism-cant-top-the-realthing. Erişim Tarihi: 25.06.2020.

McCarthy, J. (2020). What is artificial intelligence?, http://jmc.stanford.edu/artificialintelligence/what-is-ai/index.html. Erişim Tarihi: 25.06.2020.

Milliyet, (2013). Milliyet ve blippardan dev işbirliği, https://www.milliyet.com.tr/teknoloji/milliyet-ve-blippardan-dev-isbirligi-1768412. Erişim Tarihi: 19.06.2020.

Murray, M. (2018). Blockchain explained, http://graphics.reuters.com/TECHNOLOGYBLOCKCHAIN/010070P11GN/index.html. Erişim Tarihi: 20.06.2020.

Narin, B. (2015). Robot gazetecilik yay1lıyor: insan gazetecilerin sonu mu?, https://journo.com.tr/robot-gazetecilik-yayiliyor-insan-gazetecilerin-sonu-mu. Erişim Tarihi: 25.06.2020.

Narin, B. (2017). Uzman Görüşleri Bağlamında Haber Üretiminde Otomatikleşme: Robot Gazetecilik, Galatasaray Üniversitesi İletişim Dergisi, 27, 79-108.

Neal, Ryan W., (2014). Robo-Journalism: LA Times Bot Writes And Publishes Earthquake Article In 3 Minutes,https://www.ibtimes.com/robo-journalism-la-times-bot-writes-publishesearthquake-article-3-minutes-1562397. Erişim Tarihi: 26.06.2020.

Ntalakas, A., Dimoulas, C., Kalliris, G. ve Veglis, A., (2017). Drone journalism: generating 1mmersive experiences, Journal of Media Critiques, 3(11), 187-199. 
Nygren, G., Appelgren, E., ve Hüttenrauch, H. (2012). Datajournalistik - ett växande område, Nordicom-Information, 34, 81-88.

Open Knowledge (2020). "What is Open?”, https://okfn.org/opendata/. https://okfn.org/opendata/. Erişim Tarihi: 19.05.2020.

Palmerini, E., Azzarri, F., Battaglia, F., Bertolini, A., Carnevale, A., Carpaneto, J., . . Warwick, K. (2014). "Regulating Emerging Robotic Technologies in Europe: Robotics Facing Law and Ethics", http://www.robolaw.eu/RoboLaw_files/documents/robolaw_d6.2_guidelinesregulatingrobo tics 20140922.pdf. Erişim Tarihi: 23.06.2020.

Pavlik, J. V. (2013). "Yeni Medya ve Gazetecilik" (Çev.), Müge Demir, Berrin Kalsın, Phoenix Yayınevi.

Pavlik, J. V. ve Bridges F. (2013). The emergence of augmented reality (AR) as a storytelling medium in journalism, Journalism \& Communication Monographs, 15(1), 5-59.

Peddie, J. (2017). Augmented reality where we will all live. Springer.

Perez Seijo, S. (2017). "Immersive Journalism: from Audience to First-Person Experience of News", Media and Metamedia Management, (Edıtors) F. C. Freire, X. Rúas Araújo, V. A. Martínez Fernández, X. L. García (Cham: Springer International Publishing), 113-119.

Pınarbaşı, T. E. ve Astam, F. K. (2020). Haberin Dönü(şü)mü: Sosyal Medya Gazeteciliği Pratikleri, INIF-E Dergi, 5(1), 70-87.

Richterich, A. (2018). The big data agenda: Data ethics and critical data studies. University of Westminster Press.

Rogers, S. (2013). Facts are Sacred: The Power of Data. Faber \& Faber.

Rogers, S. (2020). Is Immersive Technology The Future Of Journalism?, https://www.forbes.com/sites/solrogers/2020/02/06/is-immersive-technology-the-future-ofjournalism/\#524dec607e30. Erişim Tarihi: 26.06.2020.

Rogers, S., Schwabish, J., ve Bowers, D. (2017). Data Journalism in 2017: The Current State and Challenges Facing the Field Today, https://newslab.withgoogle.com/assets/docs/datajournalism-in-2017.pdf. Erişim Tarihi: 26.06.2020.

Schönberger, M. ve Cukier, K. (2013). Big Data: A Revolution That Will Transform How We Live, Work, and Think, Houghton Mifflin Harcourt.

Sivil Havacılık Genel Müdürlüğ̈̈ (2020), https://iha.shgm.gov.tr/public/index, Erişim Tarihi: 06.06.2020.

Stone, M. L. (2014). "Big data for media", reuters institute for the study of journalism, https://reutersinstitute.politics.ox.ac.uk/sites/default/files/201704/Big\%20Data\%20For\%20Media_0.pdf. Erişim Tarihi: 15.06.2020.

Şahin, M. (2018a). Drone gazeteciliğinin haber değerine katkısı ve Türkiye pratiği, İletişim Kuram ve Araştırma Dergisi, 47(2), 261-272.

Şahin, M. (2018b). Drone Journalism, 5th International Conference on Social Sciences and Education Research, 184-191, 20-22 Nisan 2018, Antalya.

Türk Dil Kurumu Sözlükleri (2020). Veri, https://sozluk.gov.tr/. Erişim Tarihi: 15.06.2020.

Türk Dil Kurumu Sözlükleri (2020). Veri bankası, https://sozluk.gov.tr/. Erişim Tarihi: 26.06.2020.

Türk Dil Kurumu Sözlükleri (2020). Yalan haber, https://sozluk.gov.tr/. Erişim Tarihi: 26.06.2020. 
Van Dalen, A. (2012). "The algorithms behinds the headlines: how machine-written news redefines the core skills of human journalists", Journalism Practice, 6(5-6), 648-658. http://dx.doi.org/10.1080/17512786.2012.667268

Vikipedi (2020). Pokemon, https://tr.wikipedia.org/wiki/Pok\%C3\%A9mon, Erişim Tarihi: 26.06.2020

Vobic, I. (2019). Drone journalism, The International Encyclopedia of Journalism Studies Online, $1-5$.

Yöndem, T. ve Karadağ, G. H., (2019). Artırılmış gerçeklikle değişen haber sunumu, e-Journal of New Media / Yeni Medya Elektronik Dergi - eJNM, 3 (1), 22-44.

Wölker, A. ve Powell, T. E. (2018). Algorithms in the Newsroom? News readers' Perceived Credibility and Selection of Automated Journalism, Journalism, 1-18. http://dx.doi.org/10.1177/1464884918757072 